\title{
The role of probiotics to improve gut health in the elderly
}

\author{
Indra Kurniawan, ${ }^{1}$ Marcellus Simadibrata ${ }^{2}$ \\ 1 Pangkalbalam Public Health Centre, Pangkalpinang, Bangka Belitung Archipelago, Indonesia \\ 2 Division of Gastroenterology, Department of Internal Medicine, Faculty of Medicine Universitas Indonesia / \\ Ciptomangunkusumo Hospital, Jakarta, Indonesia
}

\begin{abstract}
Abstrak
Studi terkini menyatakan bahwa terdapat sebuah kelompok mikrobiota, yang dapat memberikan efek menguntungkan bagi kesehatan manusia. Kelompok ini dikenal dengan sebutan probiotik. Probiotik didefinisikan sebagai mikroorganisme hidup, non patogenik, yang bila diberikan dalam jumlah mencukupi, dapat memberikan manfaat kesehatan bagi pejamunya. Pemberian probiotik dapat mengubah komposisi mikrobiota di usus. Berbagai sediaan probiotik mempunyai peranan untuk dapat mencegah berbagai kelainan maupun menyembuhkan sejumlah penyakit. Probiotik telah menunjukkan berbagai manfaat di dalam hal melegakan konstipasi, mempercepat penyembuhan diare, menurunkan resiko kanker kolorektal, menormalkan status nutrisi, dan mengurangi gejala-gejala sindrom usus iritabel, inflammatory bowel disease, serta intoleransi laktosa. Namun, manfaat-manfaat terkait penggunaan probiotik tersebut bersifat strain spesifik. Oleh karena itu, untuk dapat memberikan manfaat kesehatan, probiotik harus diberikan dengan menggunakan regimen dosis tertentu untuk masing-masing strain probiotik, berdasarkan studi klinis yang adekuat. Meskipun pada umumnya probiotik bersifat aman, namun pemantauan yang cermat perlu dilakukan pada penggunaan probiotik untuk pasien lansia. (Med J Indones 2011; 20:226-31)
\end{abstract}

\begin{abstract}
Recent studies have reported that there is a group of microbiota, which have been shown to bring beneficial effects on human's health. They are called probiotics. Probiotics have been defined as live, non pathogenic microorganisms that, when administered in adequate amounts, confer a health benefit on the host. The administration of probiotics can change the composition of the gut microbiota. Several probiotics preparations seem to have a role in the prevention of certain diseases as well as treatment of various conditions. Probiotics have been shown to be helpful in relieving constipation, promoting recovery from diarrhea, reducing the risks of colorectal cancer, normalizing nutritional status, and improving the symptoms of irritable bowel syndrome, inflammatory bowel disease, and lactose intolerance. However, the benefits associated with probiotics are strain specific. Therefore, the use of probiotics to confer health benefits should indicate the dosage regimens of each probiotics strain, based on adequate clinical trials. Although probiotics are generally regarded as safe, careful monitoring should be performed on the use of probiotics in the elderly patients. (Med J Indones 2011; 20:226-31)
\end{abstract}

Key words: elderly, health, probiotics

Since a long time ago, it has been known that the gastrointestinal tract plays an important role in the digestion and absorption of nutrients. The gastrointestinal tract is also known as an excretory organ, since it also excretes waste end products. Furthermore, in the recent years, several studies have suggested that the gastrointestinal tract may also fulfills other functions, as the human intestinal tract contains a group of beneficial bacteria, which is known as probiotics. ${ }^{1}$

Accoding to the FAO/WHO expert consultation in 2002, probiotics have been defined as live, non pathogenic microorganisms that, when administered in adequate amounts, confer a health benefit on the host. Most of the probiotics are bacterial components of the normal human intestinal microbiota. Recent randomized controlled trials have shown that certain specific probiotics strains are effective to be used in the treatment and prevention of several diseases, both intestinal and extraintestinal origin. This review article focuses on the beneficial effects of probiotics to improve gut health in the elderly. ${ }^{1,2,3}$

Correspondence email to: indra_kurniawan@windowslive.com

\section{The concepts of probiotics}

There are many strains of probiotics, and it should be noted that not all probiotics are the same. Probiotics can be classified into several genera. Each genus of probiotics contains several species. Within each species, there are different strains, which have unique characteristics, since each strain have their own strengths and weaknesses. Like other forms of therapy, dose should be taken into consideration when giving probiotics, since each strain of probiotics have their own minimum dose. The minimum dose of each strain is determined based on levels when probiotics were found to be efficacious in large scale randomized controlled trials in human. ${ }^{4}$

Among the probiotics, lactobacillus and bifidobacteria are known as the most studied probiotics. Both of these genera are known as lactic-acid producing bacteria (LAB), which have been widely used in the food industry. Since a long time ago, probiotics are usually consumed in the form of yoghurt, fermented milks, or other forms of fermented food. Nowadays, several randomized 
controlled trials have demonstrated that probiotics are effective to be used in the management of several diseases, both intestinal and extraintestinal origin. ${ }^{4}$

\section{Microbiota in the intestinal tract}

For a long time, it has been known that the human body is colonized by approximately $10^{14}$ microbial cells. The intestinal tract, particularly colon, is suggested as the most colonized organ in the body. The composition of microbiota in the intestinal tract is different from one to another person. Several studies have demonstrated that the composition of microbiota is stable through adulthood. However, as aging process, some transformations may occur and alter the composition of the gut microbiota, since there might be a decline in immune response, increase use of antibiotics, as well as alternations in the dietary pattern. ${ }^{4,5}$

Recent studies have suggested that the intestinal microbiota may play a role in maintaining the health of the host through three different functions, including protective functions, structural functions, and metabolic functions. The protective functions include promoting the balance of inflammatory responses, and supporting the development of the immune system maturation and colonization resistance. The structural functions include increasing the capacity of intestinal barrier effects, and maintaining the health of intestinal cells. The metabolic functions include promoting the production of vitamins, improving the ability to digest nutrients and absorb minerals, and increasing the elimination of dietary carcinogens. ${ }^{4,5}$

Some recent studies have suggested that the supplementation of probiotics may confer a health benefit to the host through the mechanisms which are similiar to the roles that the intestinal microbiota involved. ${ }^{5}$ Currently, a number of bacteria and yeasts have been used widely as probiotics, such as the following :

\section{Bifidobacterium}

Some recent studies have suggested bifidobacteria as the normal microbiota of the human intestine, since these bacteria can be found in a large number in newborns within days after birth. Throughout the adulthood, the population of these bacteria is maintained in a stable number. However, as aging process, a decline in the population of these bacteria may occured. Bifidobacteria are usually classified as lactic acid bacteria (LAB). ${ }^{6}$

\section{Lactobacillus, Lactococcus and Streptococcus thermophilus}

Like bifidobacteria, lactobacilli are also considered as normal microbiota of the human intestine.
Lactobacilli can be found easily in dairy products, since these bacteria are commonly used in the fermentation of milk. Other bacteria, Steptococcus thermophilus, can also be found in milk-based products. These bacteria have been used in the production of yogurt for a long time. Lactobacillus, lactococcus and streptococcus termophilus are also classified as LAB. ${ }^{6}$

\section{Enterococcus}

Enterococci are other microbiota which can also be found in the human intestine. Recent studies have suggested the use of enterococcus faecium SF68 in the management of diarrheal illness. ${ }^{6}$

\section{Saccharomyces}

Saccharomyces is another kind of probiotics which has been widely used, particularly in the management of antibiotic associated diarrhea, in the recent years. Saccharomyces belongs to the yeast family. ${ }^{6}$

\section{Probiotic's health effects}

As mentioned before, a number of studies have shown that probiotics are effective to be used in the prevention and treatment of several diseases. However, although the administration of probiotics may confer various health effects, it should be noted that one strain of probiotics could not bring all of these things. Furthermore, different strains of probiotics, although come from the same genus and the same species, could not give the same health benefits. It should also be noted that dose should also be taken into consideration in the supplementation of probiotics, since the probiotics' health benefits are dose specific. ${ }^{7,8}$

Several randomized controlled trials have demonstrated the efficacy of probiotics in maintaining and improving the gut health. These beneficial effects are summarized in Table $1 .^{2}$

Table 1. Effects of probiotics in improving gut health

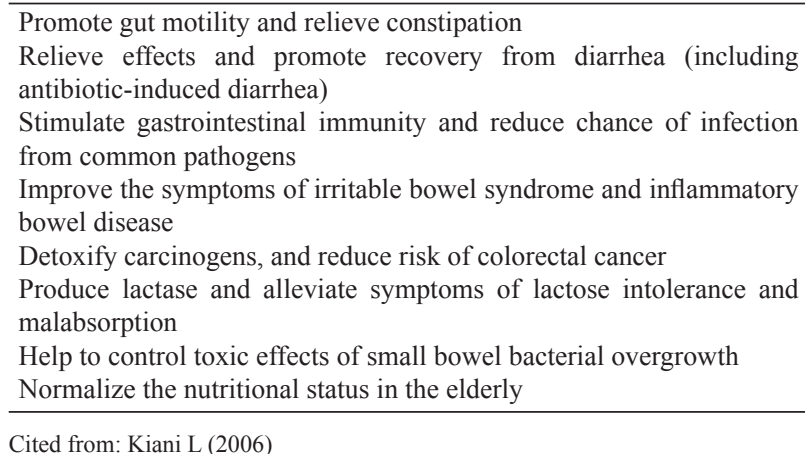

\section{Constipation}

Constipation is a common problem in the elderly. Within aging, the population of bifidobacteria is reduced. As a 
consequence, the composition of intestinal microbiota is altered. Recent studies have suggested that constipation in the elderly is strongly associated with changes in the composition of intestinal microbiota. Therefore, it is recommended to increase the number of bifidobacteria by supplementation of probiotics. ${ }^{2}$

On the other hand, several clinical controlled trials have suggested that supplementation of other probiotics, such as Lactobacillus casei Shirota strain, is also effective in relieving constipation. Furthermore, the symptoms of moderate or severe constipation were also decreased in the probiotics group, when compared to the control group. Although seems promising, larger controlled studies are needed to confirm the efficacy of probiotics in the treatment of constipation in the elderly. ${ }^{9}$

\section{Infective diarrhea}

The intestinal function is altered in many cases of diarrhea, regardless of the causes. Some recent studies have shown that the the incidence, as well as the duration of diarrhea, can be decreased with the supplementation of probiotics. Moreover, other studies have reported that the severity of diarrhea is reduced in group given yoghurt containing lactic acid bacteria, such as Lactobacillus acidophillus and bifidobacteria, when compared to the control group. ${ }^{6,7}$

It has been assumed that the supplementation of probiotics might bring beneficial effects to the immune system. Furthermore, other data have shown that the probiotics, when consumed regularly, is also effective in preventing infective diarrhea, as probiotics might compete with the pathogenic viruses or bacteria in binding to the epithelial cells. Currently, several metaanalyses have recommended the use of probiotics, as an adjunctive to rehydration therapy, for adults with acute-infectious diarrhea. However, further studies are needed to confirm the efficacy of probiotics in the treatment of infective diarrhea. ${ }^{1,8}$

\section{Antibiotic associated diarrhea}

The consumption of antibiotics might bring several adverse effects, particularly in the elderly. One of the adverse effects is antibiotic-associated diarrhea (AAD), which occur in about $20 \%$ of patients who consume antibiotics. AAD is defined by WHO as having at least three abnormal loose bowel movements per 24 hours, after receiving antibiotics. Diarrhea can be seen at any point from the beginning of therapy to two months after discontinuation of antibiotics. However, in most cases, diarrhea is occured within 7 to 14 days, after the initiation of antibiotics. ${ }^{3,5}$

It has been postulated that antibiotics may alter the composition of the gut microbiota, thereby compromising colonization resistance and promoting the growth of pathogenic microorganisms. Several studies have shown that Clostridium difficile is the most common cause of AAD. AAD should be considered as a serious problem in the elderly, as the mortality caused by AAD is several folds higher in the elderly, when compared with the younger populations. , $^{3,5,10,11}$

Since AAD is commonly caused by a change in the composition of the gut microbiota, some recent studies have suggested that the addition of the normal gut microbiota, as given by the supplementation of probiotics, is useful in the prevention and treatment of AAD. However, it should be noted that not all probiotics are equal, since each strain of probiotics has their own characteristics, including pathophysiological mechanisms and clinical indications. ${ }^{2,5,10,12}$

Some randomized controlled trials have shown that the use of several probiotic strains, such as Bifidobacterium longum, Lactobacillus acidophilus, Lactobacillus rhamnosus, Enterococcus faecium and Saccharomyces boulardii, is associated with a significant decrease in the incidence of AAD, when compared to the control group. However, data on the use of probiotics in the elderly is still limited. $2,5,10,12$

\section{Irritable Bowel Syndrome}

IrritableBowelSyndrome(IBS)is a commongastrointestinal problem in the elderly. IBS is characterized by the presence of persistent symptoms, such as chronic abdominal pain or discomfort, and altered bowel habit, for at least six months, in the absence of any organic abnormalities. ${ }^{9,13}$

Current studies have suggested that a number of mechanisms may play a role in the development of IBS. Several studies have shown that there is an alteration in the composition of the gut microbiota in patients with IBS. This may lead to the development of immune dysfunction in the gut mucosa. As a consequence, the intestinal permeability could be impaired, resulted in increased access for pathogen or its products to the subepithelial compartment. Finally, immune system may be activated, and inflammatory mediators may be released as a final result of these processes. ${ }^{5,14}$

Anumber of studies have shown that the supplementation of probiotics, such as specific strain of Bifidobacterium animalis and Bifidobacterium infantis, is effective in reducing the symptoms of IBS, including constipation, since probiotics may play a role in stimulating the intestinal transit. Moreover, other studies have demonstrated that probiotics is also clinically effective in improving pain and other cardinal symptoms for all subgroups of patients with IBS. 5,13,14,15 
Some recent studies reported that probiotics have shown promising results in the treatment of IBS. The supplementation of probiotics may restore the normal composition of the gut microbiota. Probiotics therapy may also improve the epithelial barrier, so that the intestinal permeability could be restored. Furthermore, other studies have demonstrated that probiotics therapy is also effective in reducing various inflammatory mediators. However, although the effectiveness of probiotics in the treatment of IBS seems promising, large controlled studies are still needed to confirm its efficacy in elder patients with IBS. $5,9,13$

\section{Inflammatory Bowel Disease}

Current studies have reported the effectiveness of probiotics therapy in improving the symptoms of Inflammatory Bowel Disease (IBD), such as ulcerative colitis and Crohn's disease. Until now, the etiologies of IBD are still unknown. Some recent studies have suggested that a number of factors may play a role in the development of IBD symptoms, including immunological reaction, inflammatory response, as well as disturbance in the composition of the gut microbiota. ${ }^{3,4}$

Several studies have demonstrated that probiotics therapies have shown promising results in improving the symptoms of IBD, since probiotics might play a role in restoring the normal composition of the gut microbiota, stabilizing immunological reaction as well as inflammatory response. A number of controlled clinical trials have demonstrated that the supplementation of certain probiotic strains, such as Saccharomyces boulardii, Lactobacillus acidophilus, Lactobacillus bulgaricus, Lactobacillus casei, Lactobacillus plantarum, Bifidobacterium breve, Bifidobacterium infantis, Bifidobacterium longum and Streptococcus thermophilus, is effective in relieving the symptoms of IBD and preventing the relapse. However, further studies are needed to confirm the clinical effectiveness of probiotics in the treatment of IBD. ${ }^{1,3}$

\section{Colorectal Cancer}

Within ageing, the incidence of colorectal cancer (CRC) is increased. It has been hypothesized that a number of factors might contribute to the development of CRC in the elderly, including dietary factor (high fat-low fiber diet), disturbance in the composition of the gut microbiota, and reduced function of the ageing microbiota. ${ }^{1,3}$

Several studies have demonstrated that the supplementation of probiotics has shown promising result in preventing $\mathrm{CRC}$, since probiotics might play an important role in various anti-mutagenic mechanisms, such as promoting the elimination of potential carcinogens, improving the metabolic activities of intestinal microbiota, increasing the production of anti-mutagenic substances, and improving the immune response of the host. ${ }^{1,7}$

It has been postulated that several biomarkers may also contribute to the development of CRC. Several studies have shown that pathogen bacteria, particularly clostridia and bacteroides, may produce toxic substances by converting dietary constituents into mutagenic components, including $\beta$-glucuronidase, $\beta$-glycosidase, and azoreductase. Some recent studies have suggested that the supplementation of certain probiotic strains, such as Lactobacillus acidophilus, Lactobacillus gasseri, Lactobacillus confuses, Bifidobacterium longum, Bifidobacterium breve and Streptococcus thermophilus, is effective in reducing the conversion of these enzyme activities. Although seems promising, further studies are needed to confirm the efficacy of probiotics in preventing CRC. ${ }^{3}$

\section{Lactose Intolerance}

Lactose intolerance is a common condition in the population, included in the elderly. In individuals with lactose intolerance, the digestion of consumed lactose is impaired. As a consequence, the undigested lactose will be fermented by the intestinal microbes, resulted in the increased production of gas and water. Several studies reported that the symptoms of lactose intolerance in the elderly are more severe, when compared to the younger populations. However, it should be noted that the older persons need to consume dairy products to maintain the bone health and prevent osteoporosis. Therefore, lactose intolerance is considered as an important problem in the elderly. ${ }^{6,7}$

Some recent studies have shown that in individuals with lactose intolerance, yoghurt is more tolerable than raw milk. Several studies have demonstrated that $\beta$-galactosidase (lactase) activity of the bacteria used to ferment yoghurt (Lactobacillus bulgaricus and Streptococcus thermophilus), may play an important role in hydrolizing lactose into glucose and galactose, which is more tolerable for those with lactose intolerance. Thus, individuals with lactose intolerance can consume yoghurt in a greater degree than raw milk. However, several large controlled trials are needed before concluding that the supplementation of probiotics is effective in reducing the symptoms of lactose intolerance. ${ }^{1,3,6,7}$

\section{Small Bowel Bacterial Overgrowth}

Small Bowel Bacterial Overgrowth (SBBO) is a condition where the population of microbials in the small intestine is increased beyond the normal level. SBBO is commonly occured in certain conditions, such 
as low production of stomach acid or kidney dialysis. Several studies have suggested that the presence of SBBO is strongly associated with an increased production of toxic substances, which is harmful to the body. Therefore, several efforts have been made to manage SBBO. ${ }^{6}$

Current studies have demonstrated that the supplementation of probiotics, such as Lactobacilli and Saccharomyces boulardii, is effective in reducing SBBO and restoring the normal composition of the gut microbiota. However, further evaluation is needed to confirm the effectiveness of probiotics in the management of SBBO. ${ }^{6}$

\section{Malnutrition}

Epidemiological studies have suggested that malnutrition is a common condition in the elderly. Approximately $7 \%$ of older persons suffer from malnutrition. On the other hand, the incidence is doubled in individuals aged $>80$. In the elderly, malnutrition can cause a number of negative impacts, since it may cause damages to the intestinal epithelium, impair immune response, as well as absorption of dietary constituents. Moreover, in individuals with malnutrition, the intestinal permeability is impaired. As a consequence, there is an increased access for pathogen bacteria to enter the circulation, resulted in septicemia and infection in many parts of the body. ${ }^{2}$

Some recent studies have shown that the supplementation of probiotics, such as Lactobacillus acidophilus, Streptococcus thermophilus, and Bifidobacterium lactis, has shown promising results in the normalization of nutritional status in children. Moreover, current studies reported that probiotics has been recommended by $\mathrm{WHO}$ as an adjunctive therapy for nutritional deficiency. Although seems promising, a number of clinical controlled studies are needed to confirm the effectiveness of probiotics therapy to correct malnutrition in the elderly. ${ }^{2}$

\section{Availability of probiotics}

A number of bacterial genera and species have been used in probiotic products, including Lactobacilli, Bifidobacteria, Enterococcus, Eschericia coli, and yeast. For organisms to be classified as probiotics, there are several criteria which need to be fulfilled, such as : (a) recognized as safe, based on multiple studies, (b) still viable during production processes, (c) still stable during exposure to acid and bile, (d) able to attach to the epithelium of the gut, and (e) able to reduce negative impacts caused by pathogens or their products. ${ }^{7}$

Currently, probiotics are available in various forms of product. The first form of probiotics product is yoghurt. It is considered as the most well-known probiotic products. Furthermore, probiotics are also available in milk-based food products. Other probiotics products are dietary supplements, such as powders, capsules, or tablets, which consist of concentrated or dried cells. ${ }^{2,7}$

\section{Safety aspects}

A number of probiotic products are widely available in the recent years. However, the concentration of probiotics in food products are varied widely, since there is no standard in determining the level of bacteria required in the probiotic products. Several studies have reported that probiotics are usually consumed at a range from one to ten billion colony-forming unit (CFU). Other studies have demonstrated that probiotics are recommended to be consumed at least a few times a week to give an optimal effect to the health of the gut. ${ }^{6}$

In general, probiotics products are considered as safe, since they do not cause adverse effects even if given in a high dose to older persons with a low state of immune response, based on several studies. Furthermore, other studies have shown that probiotics could be given to patients after having invasive surgery, without causing any adverse effects. Although probiotics are classified as bacteria, they are not selected among pathogens. Therefore, the risk of infection caused by supplementation of probiotics is extremely low. However, probiotics could not be given for those who are sensitive to any component of a probiotic-containing product. ${ }^{6}$

\section{Adverse reactions}

Like other medications, probiotics therapy may also cause several adverse effects, particularly related to the gastrointestinal system, including flatulence and constipation. However, no serious adverse effects have been observed in the supplementation of probiotics, based on numerous epidemiological studies. ${ }^{1,2}$

In conclusion, probiotics have been defined as a group of bacteria in the intestinal tract that could bring beneficial effects for human's health. Current studies have shown that supplementation of probiotics may bring a number of health effects to the host. Since probiotics work in strain-specific manner, it is important to learn from several studies, based on data from in vitro, animal dan human studies, to understand the strain-specific characteristics and health outcomes. Furthermore, although the probiotics therapy is considered as safe, proper monitoring should be taken into consideration in the supplementation of probiotics to the elderly.

\section{REFERENCES}

1. Harish K, Vargese T. Probiotics in humans - evidence based review. Calicut Med J. 2006;4:e3. 
2. Hamilton JM, Miller. Probiotics and prebiotics in the elderly. Postgrad Med J. 2004;80:447-51.

3. Tuohy KM, Probert HM, Smejkal CW, Gibson GR. Using probiotics and prebiotics to improve gut health. DDT. 2003;8:692-9.

4. Walker WA, Sanders ME, Walker WA, Guandalini S, Meydani S. Proceedings of the Symposium Practical Applications of Probiotics in Health and Disease. American College of Nutrition. 2009:4-11.

5. Floch M, Sanders ME, Guandalini S, Quigley E. Probiotics : applications in gastrointestinal health \& disease. Proceedings of the Symposium in conjunction with American College of Gastroenterology Annual Scientific Meeting. 2007:4-9.

6. Kiani L. Bugs in our guts - not all bacteria are bad: How probiotics keep us healthy. CSA Discovery Guides. 2006.

7. Ogueke CC, Owuamanam CI, Ihediohanma NC, Iwouno JO. Probiotics and prebiotics: unfolding prospects for Better human health. Pakistan J Nutr. 2010;9:833-43.

8. Gilliland SE, Morelli L, Reid G. Health and nutritional properties of probiotics in food including powder milk with live lactic acid bacteria. Report of a Joint FAO/WHO Expert Consultation on Evaluation of Health and Nutritional Properties of Probiotics in Food Including Powder Milk with Live Lactic Acid Bacteria. 2001:7-18.
9. Weichselbaum E. Potential benefits of probiotics - main findings of an in-depth review. British J Com Nurs. 2009; $15: 110-4$

10. Safdar N, Barigala R, Said A, McKinley L. Feasibility and tolerability of probiotics for prevention of antibioticassociated diarrhoea in hospitalized US military veterans. J Clin Pharm and Therapeutics. 2008;33:663-8.

11. Plummer S, Weaver MA, Harris JC, Dee P, Hunter J. Clostridium difficile pilot study: effects of probiotic supplementation on the incidence of $\mathrm{C}$. difficile diarrhoea. Int Microbiology. 2004;7:59-62.

12. Bartlett, JG. Historical perspectives on studies of Clostridium difficile infection. Clin Infect Dis. 2008;46:S1-4.

13. Andresen V, Baumgart DC. Role of probiotics in the treatment of irritable bowel syndrome: potential mechanisms and current clinical evidence. Int $\mathrm{J}$ of Probiotics and Prebiotics. 2006;1:11-8.

14. Lembo AJ. Advance in IBS : current developments in the management of motility disorders and irritable bowel syndrome. Gastroenterol \& Hepatol. 2008;4:118-22.

15. Saggioro A. Probiotics in the treatment of irritable bowel syndrome. J Clin Gastroenterol. 2004;38:S104-6. 